\title{
Cape Bretoners in the Victoria Sealing Fleet, and beyond
}

\section{Don MacGillivray}

Les marins de Cap Breton, dont l'industrie a atteint sa majorité dans les années 1880, ont été confrontés par un fort déclin de la voile dans les provinces maritimes. Par dizaines, ils se sont dirigés vers la flotte croissante de la pêche pélagique basée à Victoria en Colombie Britannique. Beaucoup sont devenus patrons réussis, et en raison des issues diplomatiques, légales et de conservation tourbillonnant autour de la dispute de la mer de Béring, ils ont attiré un grand intérêt de la part des gouvernements, $d u$ grand public, des journalistes et des romanciers. Voici, brièvement, leur histoire.

On a spring day in 1888 the bustling port of Victoria had its cultural mix enhanced with the arrival of three boatloads of Cape Bretoners. At 8:00 am on Tuesday, 24 April the 113-ton schooner Annie C. Moore under Captain Charles Hackett arrived, having departed North Sydney 158 days earlier. Thirteen hours later the Triumph, a 97ton schooner under Dan MacLean appeared, after a 128 day passage from Halifax. ${ }^{1}$ She was followed within minutes by the Maggie Mac, a 196-ton three masted schooner with Captain John Dodd at the helm, having departed Halifax on 9 November. ${ }^{2}$ Hackett was from North Sydney; Dodd was a native of Sydney; MacLean was from East Bay. The majority of the crews were also Cape Bretoners, most of them on the West coast for the first time; only Dodd and MacLean had previously sailed out of Victoria. ${ }^{3}$ A fourth schooner with a Cape Bretoner at the helm also sailed into James Bay that evening. The Mary Ellen, under Alex MacLean, Dan's brother, returned from a nine-week sealing trip along the coast with the largest catch reported to date, entitling the vessel to "carry the broom" as she sailed into port. ${ }^{4}$ The most successful schooner would hoist a broom on the main halyard signifying a clean sweep. ${ }^{5}$

1 The Triumph was originally registered on 2 April 1887. Declaration by Mary Blackett, 13 August 1889, R.H. Roy Collection, Add. MSS. 995, British Columbia Archives and Records Service (BCARS).

2 Victoria Times, 24 April 1888; Victoria Colonist, 24 April 1888.

3 Victoria Times, 24 April, 1888; Victoria Colonist, 25 April 1888; Halifax Morning Herald, 9 November 1887.

4 Victoria Times, 24 April 1888; Victoria Colonist, 25 April 1888; Halifax Herald, 9 November 1887; Sydney Post, 27 September 1905.

5 Thanks to Brian Young, BCARS, and John MacFarlane, Maritime Museum, Victoria, for their assistance and information on this practice. Victoria Colonist, 25 April 1888; Gordon

The Northern Mariner/le marin du nord, XX No. 3, (July 2010), 240-249 
That April evening the saloons at Tommy Burnes' American Hotel, Erickson's Hotel at the foot of Johnson Street, the Garrick's Head on Bastion Street and other waterfront spots surely rang with a variety of Cape Breton dialects. ${ }^{6}$ The Cape Bretoners in Victoria for the first time were probably fascinated with their new home port. It was quite a change from picturesque Arichat, sleepy Sydney or rustic East Bay. The 1880s was Victoria's decade, and as Ivan Doig phrased it, through the lens of diarist James Swan: "Not at all like the dry and dowdy little Queen whose name it wears ... the city is in the manner of the youngest daughter of some Edwardian country house family, attractive and passionately self-absorbed and more than a little silly."7 Maybe a bit risqué as well for the innocent Cape Bretoners, considering the openly advertised opium joints and the Johnson Street brothels. ${ }^{8}$ At this time, Victoria "had the largest red-light district on the Northwest Coast" " and sources suggest that a section of the waterfront was "a miniature Barbary Coast full of sailors and gamblers, whores and drunks ... The men were wild and free and the women just as mad." $" 10$

Most of these Cape Breton mariners were born in the 1850s and 1860s and came of age when the "great days of sail" period was peaking. In 1880 Canada had probably "the fourth largest merchant marine in the world," with almost 75 percent registered in what is now Atlantic Canada. Two decades later local fleets had declined by two-thirds. The "golden age" there had barely lasted a generation. ${ }^{11}$ Given the limited economic opportunities for Cape Bretoners, large numbers went down to the sea in coastal vessels, long distance trade and banks fishing, the latter primarily in American schooners from New England ports. With the protective tariff the 1880s would see significant increases in secondary manufacturing in the region; such land-based economic opportunities help explain the rapid decline in vessel ownership. But few of the new factories located in Cape Breton. ${ }^{12}$ Almost 10,000 migrated from the island in the 1880s, twice the rate of the previous decade. $^{13}$

Newell, Pacific Steamboats (New York 1958), 42.

6 D'Arcy Marsh noted that the Erickson was a favourite haunt of Alex's. "London's Sea Wolf in Scot's Clothing," Vancouver Province, 31 May 1958, 15.

7 Ivan Doig, Winter Brothers: A Season at the Edge of America (New York 1980), 227.

8 Charles Lillard, Seven Shillings a Year: the History of Vancouver Island (Ganges, B.C. 1986), 173-5; Cecil Clark, "Seawolf McLean Tweaked Russia's Beard," Victoria Colonist, 5 April 1959, 8.

9 Lillard, Seven Shillings a Year, 171. See also Patrick Dunae, "Geographies of sexual commerce and the production of prostitutional space": Victoria, British Columbia, 18601914, Journal of the Canadian Historical Association New Series, 19, 1 (2008), 115-142.

10 Norman Hacking, "The Victoria Sealing Fleet," The Sea Chest (Spring 1982), 97.

11 Eric Sager with Gerald Panting, Maritime Capital: The Shipping Industry in Atlantic Canada, 1820-1914 (Montreal/Kingston 1990), 4, 88.

12 T.W. Acheson, "The National Policy and the Industrialization of the Maritimes, 1880-1910," Acadiensis 1, no. 2 (Spring 1972), 5.

13 Stephen J. Hornsby, Nineteenth Century Cape Breton: An Historical Geography (Montreal/Kingston 1992), 188-200. 
In Atlantic Canada at this time ownership of sailing vessels was concentrated in the hands of fewer and fewer individuals. It was a different scene with the emerging sealing fleet in Victoria. In 1882 the fleet numbered thirteen vessels. ${ }^{14}$ The following year the City of San Diego, with the MacLean brothers aboard, made a seminal voyage to the Bering Sea, probably the first occasion in which a vessel entered those waters specifically for sealing. The City of San Diego remained there from June to mid-September. ${ }^{15}$ Within a decade there were around 70 sealing schooners based in Victoria; the combined west coast fleet numbered 124. ${ }^{16}$ Victoria was fast becoming "the world's premier sealing port."17 This rapid expansion was quite egalitarian, attracting a tough and varied crowd with room for determined newcomers. Tony Busch's excellent study, The War Against the Seals, notes the largest group was from the Maritimes, and he

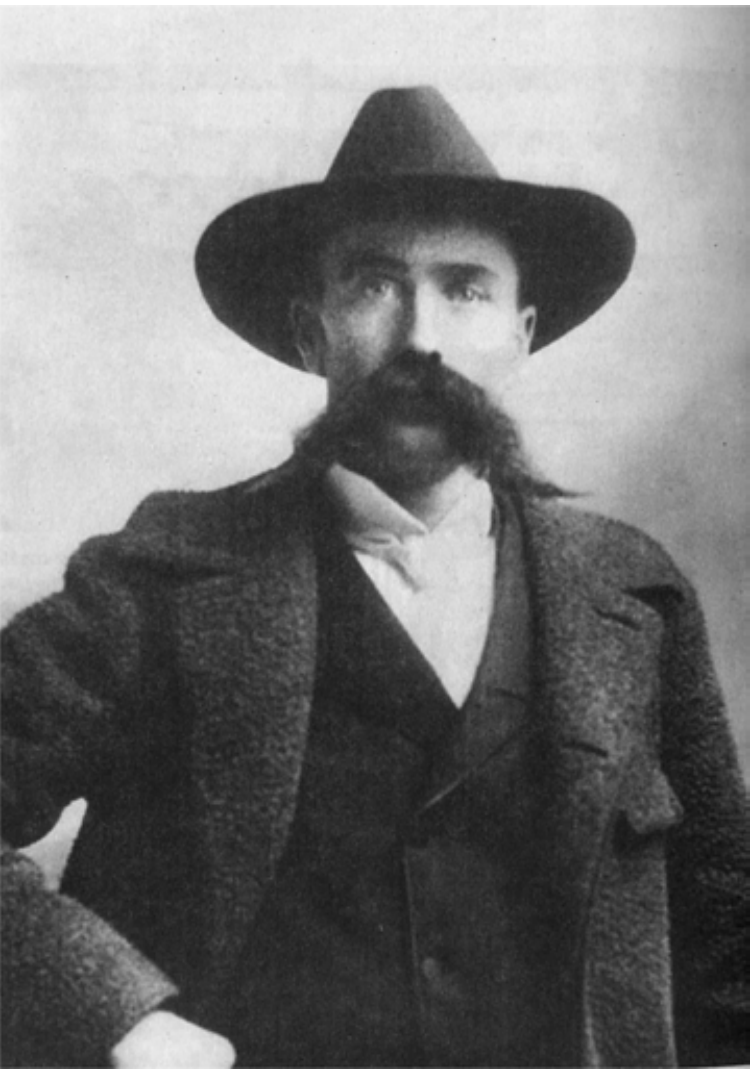

Illustration 1: Alex MacLean with Stetson hat.

Courtesy of Carol Brookman. singled out mainland Nova Scotia in particular, contributing "at least a dozen well-known captains" to the fleet. ${ }^{18}$ But there were at least fourteen Cape Breton master mariners involved as well. ${ }^{19}$ Part of the

14 Library and Archives Canada, RG 8, series 3, vol. 23, 59; United States, Congress, Treasury, The Fur Seals and Fur Seal Islands of the North Pacific Ocean, 3, 223; NA, RG 33, series 107, vol. 3, file 13, pt. 34, 346

15 United States, Congress, Bering Sea Claims Commission, Record of Evidence Taken in Victoria, British Columbia by the Commissioners under the convention of 8 February 1896 between Great Britain and the United States (Washington, 1897), v. 1: 400, 430-32 and 467; Victoria Daily Colonist, 12 October 1883, 5.

16 E.W. Wright, ed., Lewis \& Dryden's Marine History of the Pacific Northwest (Portland 1895), 428; Bering Sea Claims Commission, Evidence, 1: 460; Congress, House, Department of Commerce and Labor, Report from Committee on Expenditures in Department of Commerce and Labor, in relation to fur-seal industry of Alaska, 31 January 1913, 2; Briton Cooper Busch, The War Against the Seals: A History of the North American Seal Fishery (Montreal/Kingston 1985), 137.

17 Busch, 143.

18 Busch, 140-1.

19 Dan MacLean, Alex MacLean, Alf Bissett, Charles Hackett, Fred Hackett, Melville Cutler, 
explanation for the significant participation of Cape Bretoners was the early successes of Alex and Dan MacLean. In 1886 Alex, in the Favorite, brought in the second highest catch of the season. Dan and the Mary Ellen returned with a record 4,268 skins. It would be surpassed only once in the history of the fleet. ${ }^{20}$ The sealing record of the MacLean brothers in the 1884-87 period was impressive. With an average price in Victoria in the 1880 s of $\$ 7$, they acquired over 18,000 skins, equal to $\$ 126,896 .^{21}$

In October 1887 Dan MacLean was in Nova Scotia to acquire a new vessel, and his arrival prompted considerable local interest. ${ }^{22}$ The Halifax waterfront was already abuzz with the knowledge that a number of Nova Scotia schooners had recently departed for the trip around Cape Horn. Eight east coast schooners headed to Victoria that year. They included the Sapphire, Viva, La Houlette, Araunah, and Ariel. ${ }^{23}$ With one of the leading skippers of the Victoria fleet in its midst, and a local man, the Halifax Herald was impressed: "There is a great future for this fishery; there is room for almost any number of enterprising men, and there's lots of money in it ... Cape [Bretoners] are already to the fore - as they always are when opportunities offer." ${ }^{24}$ Dan purchased the Triumph. ${ }^{25} \mathrm{He}$ was also directly responsible for an additional bunch of Cape Bretoners making the trip. "When the Triumph, with the sails set, was ready to leave, seven Cape Breton boys nearly all of North Sydney, who happened to be employed in Halifax, were invited aboard to have supper." While dining, the lines were loosened and the schooner drifted out. When they came on deck they were off Point Pleasant. MacLean told them their next port was Victoria, explaining he had written their relatives that they were sailing, promised "good wages" on the voyage and guaranteed good jobs in their new home port at twice their Halifax wages. ${ }^{26}$ Dan's assurances, the opportunities on the west coast and the seasonal slowdown of port activities in Halifax apparently alleviated the concerns of the additional Cape Bretoners aboard. ${ }^{27}$

Charles Campbell, John MacLeod, J.W. Peppitt, Matt Ryan, Charles LeBlanc, Dan MacAulay, Tom Brown, Harry Brown.

20 Clarence Nelson Cox, a Nova Scotian, would beat Dan's record in 1894 with 4,560 skins Wright, Lewis \& Dryden, 427 n.4; 435 n.19.

21 Busch, 139.

22 It was cheaper than having one built in British Columbia at the time. F.W. Wallace, "B.C. Sealers Claims Revive Memories of Old Days," Canadian Fisherman (August 1934), 19; Wright, Lewis \& Dryden, 428; Halifax Morning Herald, 16 November 1887.

23 Marine Digest, 4 May, 22, 29 June, 1957; 11 January, 8 February 1958; Beaton Institute, Cape Breton University, MG 12 50, Captain John Parker Collection. 5. The practice of Victorians purchasing eastern schooners for use in the Pacific continued until at least 1905. Victoria Colonist, 17 October 1905.

24 Halifax Morning Herald, 16 November 1887.

25 E.C. Baker diary, 16 November 1887, Add. MSS. 707, BCARS; U.S. Congress, Record of Evidence, 2, 1419-23.

26 Ronald Gillis, "The McLeans of Cape Breton and Scotland," Sydney Post-Record, 17 November 1936, 4.

27 Gillis, "The McLeans of Cape Breton and Scotland"; Judith Fingard, "The Winter's Tale: The Seasonal Contour of Pre-Industrial Poverty in British North America, 1815-1860," Canadian 
The North Pacific was a harsh and unforgiving environment. The adverse current and prevailing westerlies of the west coast made the lee shores particularly treacherous. ${ }^{28}$ Over 230 sailors and hunters in the sealing fleet, and nine schooners, were lost in the period 1888-1905. One of them was the Maggie Mac. In March 1892, Captain John Dodd and his crew of twenty-three went down somewhere between Cape Scott and Triangle Island. The average age of the crew, which included Dodd's thirteen-year-old son, was twenty-four. $^{29}$ The insurance rates were "extremely high by any marine standard." ${ }^{30}$ Another difficulty, which intensified the Bering Sea dispute, were seizures, initially by the United States; Russia soon joined in. In 1886-87 ten Canadian and nine American sealers were seized. ${ }^{31}$ When the MacLean brothers headed out in 1888, with Dan on his first trip with the Triumph, they were not particularly perturbed by that possibility. As they told a reporter: "blows, bluff, or a clean pair of heels will prevent them from being taken by any American revenue cutter pirate."32 Other sealers shared that approach; as Victor Jacobsen remembered it: "They were great days. Half the fascination of sealing was in dodging the gunboats." 33 The sealers also had other options. When one captain was leaving port he mentioned he "intends to protect himself if molested by American cutter pirates." ${ }^{34}$ Others in the front lines noted, and followed, the militant attitude and response. ${ }^{35}$ Some of those seized did not stay seized; some simply continued hunting the presence of a prize crew notwithstanding — and then returned to their home port. In 1889 the officers aboard the American cutter Bear were worried because "no one wanted to go to Victoria as a prize crew." 36

Historical Association Historical Papers (1974), 65-94.

28 Nichols, 124; Elmer Green, ed., Adventures of Carl Rydell: The Autobiography of a Seafaring Man (London1924), 72-4; Busch, War Against the Seals, 131-3; E.M. Sweeney, "Rescue on the sealing grounds," Victoria Colonist, 1 January 1972, 6; D.G. Paterson and J. Wilen, "Depletion and Diplomacy: The North Pacific Seal Hunt, 1886-1910," in P. Uselding, ed., Research in Economic History (Greenwich 1977), 107, citing G. Nicholson, Vancouver Island's West Coast (Victoria 1965); J. Gordon Smith, "The Romance of Sealing," Canadian Magazine 21, no. 5 (September 1903), 401.

29 Wright, Lewis \& Dryden, 437-8; Ursula Jupp, ed., Home Port: Victoria (Victoria 1985), 115. The schooners were mostly two-masted, between 60 and 120 tons.

30 Eva Marie Sweeney, Add. MSS. 792/2/2, 25, BCARS, Victoria; Victoria Colonist, 1 January 1972.

31 Robert Craig Brown, Canada's National Policy 1883-1900: A Study in Canadian-American Relations (Princeton 1964), 48-9; Congress, Fur Seal Arbitration, The Counter Case of the U.S., v. 2; Norman Hacking, "The Victoria Sealing Fleet," The Sea Chest (Spring 1982), 101. Victoria Colonist, 1 May 1888.

33 N. de Bertrand Lugrin, "Epic of the Seal Hunters," Canadian Geographical Journal 4, no. 5 (May 1932), 295.

34 Victoria Colonist, 17 March 1888; Wright, Lewis \& Dryden, 430-32.

35 "Despairing of any help from British diplomacy or the British navy, the sealers determined to defend themselves and for that purpose arranged to take large crews of armed Indians in their vessels." Up to March 1888, "no effective or even earnest step had been taken by the Foreign Office.” John S. Ewart, British Protection, Bering Sea Seizures (Ottawa 1913), 68. 


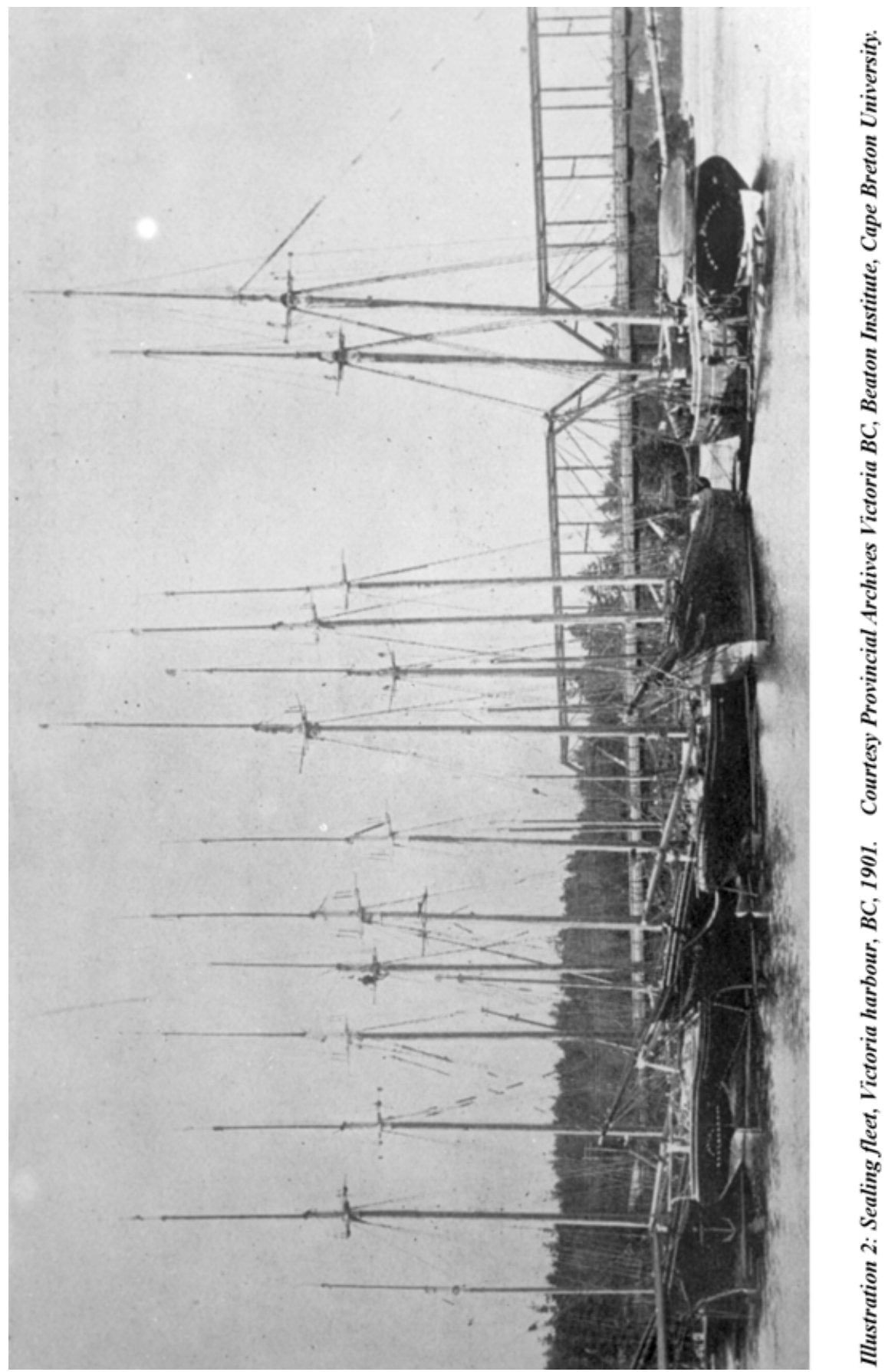

3B, v.23, Admiralty, enclosure 5 in No. 92; Victoria Colonist, 30 August 1889; Brown, Canada's National Policy, 102; Gerald O. Williams, "Michael J. Healy and the Alaska Maritime Frontier" (MA thesis, University of Oregon, 1987), 188. 
The Victoria-based sealers were a feisty, talented bunch and they were soon viewed through a romanticized hue. In a 1903 article, "The Romance of Sealing," J. Gordon Smith noted: "They are a varied gathering of sailormen these sealers, but for adventure, or for fun and story, the jolly Cape Breton boys, or the hardy men from Nova Scotia or New Brunswick lead them all ... It will be difficult to find a hardier or more daring class of men than these brave fellows who man the sealing fleets." ${ }^{37}$ Another assessment simply stated: "they were a tough bunch of men." ${ }^{38}$ Many of the other sealers, such as Victor Jacobsen (Finland), Max Lohbrunner (New York), Luke McGrath (Halifax) and the "Flying Dutchman," Gus Hansen, also fit the descriptions. ${ }^{39}$ While Dan and Alex MacLean left the Victoria fleet in 1889 for San Francisco, where their activities would soon fascinate a young Jack London, others continued to arrive. ${ }^{40}$ As one young Cape Bretoner in Victoria would write home in the early 1890s: "It would but surprise you to know the number of C.B. men here in the sealing business and at other things." The writer was one of three Cape Bretoners with the Victoria Fire Department. ${ }^{41}$

Most Cape Bretoners, then and now, readily acknowledge a shared identity, particularly if off-island. So did others; in the early 1890s, with the Bering Sea dispute bubbling on high, the American consulate in Victoria did a breakdown on the origins of sealers in the fleet and Cape Breton had a separate category from Nova Scotia. ${ }^{42}$ These Cape Breton mariners stuck together. For example, North Sydney native Tom Brown arrived on the Annie C. Moore with Captain Hackett in 1888. He went sealing that season as a boat puller with John Dodd on the Maggie Mac. ${ }^{43}$ Anxious to be a hunter, the following year Brown discovered a schooner, the Mary Ellen, was off sealing the next morning and was still short a hunter. Brown tracked the MacLeans down to the bar at the American Hotel. Brown did not know Alex "but was acquainted with Captain Dan, and counted on him to make the introduction." Brown's approach, "that I was a 'towny' of theirs and that I should 'make good' because of that" was successful. ${ }^{44}$ In 1891 Brown visited North Sydney and the local paper carried a detailed report from him listing the vessels, captains and catches of the fleet that season. That list had 16 Nova Scotia vessels; many were captained by Cape Bretoners. ${ }^{45}$ Brown also convinced his brother,

37 J Gordon Smith, "The Romance of Sealing," 393, 401.

38 Imbert Orchard, "Days of the Sealing Fleet: People in Landscape," interview with Jimmy Newman, Max Lohbrunner, Noel Robinson, No. 2466, 1970, BCARS.

39 Busch, 141.

40 Don MacGillivray, Captain Alex MacLean: Jack London's Sea Wolf (Vancouver 2008), 103105.

41 John McNeil to James McNeil, Victoria, 4 August 1891, 2 October 1892, James McNeil Correspondence, Greg Mcdonald, Halifax; Elva E. Jackson, North Sydney, Nova Scotia: Windows on the Past (Belleville 1982), 13, 39, 119.

42 L.W. Myers to State, 19 September 1892, BCARS, American Consulate Records, Victoria, A-735.

43 Post-Record, 28 September 1935.

44 Frank Kelley, "Sealing with the Sea Wolf," Victoria Colonist, 18 June 1933, magazine, 1.

45 In October 1891, for example, the North Sydney Herald commenced a piece prompted by Brown's visit with "Half the Fleet are from this Province and they Succeed Best." Halifax 
Captain Harry Brown, to head west for sealing that year. ${ }^{46}$ Tom Brown would continue to go seal hunting well into the $1890 \mathrm{~s} .{ }^{47}$ His stories are suggestive, both for some of the direct ways information about activities in the North Pacific found its way back to Cape Breton and the close connection among Cape Bretoners in the fleet.

Many of these mariners remained on the west coast for long and successful careers. Charlie Harris, from Gabarus Bay, arrived in Victoria in 1888. A successful sealer, he then became a harbour pilot, holding BC pilot certificate No. 2. Harris was the pilot when the battle cruiser HMS Hood steamed into Victoria on 25 June $1924 .{ }^{48}$ On his hundredth birthday he said he would go to sea again if he was ten years younger, although he now found flying more exciting. The newspaper lead for his obituary in his 102 $2^{\text {nd }}$ year: "Ancient Mariner Crosses the Bar." ${ }^{, 9}$ Fred and Charles Hackett would eventually be considered among "the foremost navigators of the North Pacific." ${ }^{50}$ Alf Bissett, from River Bourgeois, was first mate on the Triumph when she came around the Horn in 1888. Captain Bissett would later be described as "one of Vancouver's best known maritime pioneers" and he died there at the age of $87 .{ }^{51}$

Charles LeBlanc, from West Arichat, started on the Maggie Mac in 1888, then on the Mary Ellen, the Carmolite and the Annie E. Paint (Bissett's schooner) before commanding a vessel. ${ }^{52}$ Like numerous sealers LeBlanc was briefly attracted to the Klondike. After a few months he took the Yukon River passage out, ending at St. Michael, Alaska, in the Bering Sea, eager to work his way south. He approached the captain of a San Francisco-based vessel, who acknowledged he could use an experienced A.B. and asked him his name. LeBlanc answered, and the captain responded: "Do you belong to Arichat?" He was a MacLeod from Cleveland, about ten kilometres from LeBlanc's village. ${ }^{53}$ LeBlanc retired to Arichat and died at 95 in $1959 .{ }^{54}$

Charles LeBlanc was a "good friend" of Matt Ryan. ${ }^{55}$ Born at Cape Dauphin, Cape Breton, Ryan was probably onboard the Carmolite when Melville Cutler, from Arichat, took her around the Horn from Sydney in 1889. Boisterous winds off Cape Horn

Herald, 24 October 1891, 1.

46

47

Victoria Colonist, 23 October 1910.

Wright, Lewis \& Dryden, 453-4; Jackson, North Sydney, 39.

Victoria Times, 4 February 1969.

Ibid.

B.A. McKelvie, "Saga of Sealing," Add. MSS, 10-11, BCARS. See also John Parker, Cape Breton Ships and Men (Aylesbury 1967), 58, 82, 89; Jackson, North Sydney, 39, 46.

Vancouver Sun, 6 May 1948; Alf Bissett, Vertical file, BCARS.

Cape Breton, 1881 census, District 7/K/47/207; Royal Commission to Investigate and Report upon Claims of Certain Canadian Pelagic Sealers, 1913-1915, RG 33, 107, 1, 5, 27-39.

Agnes G. Donahoe file, M74.38.2, Maritime Museum of the Atlantic, Halifax. Brothers David, Charles and William McLeod were all master mariners. Captain David A. McLeod, Cape Breton Captain (Wreck Cove, CB: Breton Books, 1992.)

Halifax Chronicle-Herald, 30 January 1959, 11.

Conversation with Murray Ryan, North Sydney, 20 November 2005. 
prevented the vessel from logging a single mile for fifty days. ${ }^{56}$ That was no reflection on Cutler; in 1893, with the 107-ton Agnes McDonald, he logged 307 miles in 24 hours on a sealing voyage to Japan. $^{57}$ Like LeBlanc, Ryan learned the sealing business crewing on Cape Bretoncaptained vessels until he took command in $1898 .^{58}$

Ryan had his share of adventures and misadventures during a sealing career that spanned 33 years. In the early 1900s Ryan, LeBlanc and a handful of other sealers were attracted to other sealing grounds around the Falkland Islands, Uruguay, and deep into the Southern Ocean. ${ }^{59}$ In 1903 the Agnes G. Donahue, under Captain Ryan, was one of eleven schooners that departed from Halifax. ${ }^{60}$ Planned as a two year cruise, it was extended when seized in November 1904 by a gunboat from Uruguay and taken to Montevideo harbour. ${ }^{61}$ Confined to the vessel, Ryan had a five year sentence at hard labour hanging over his head for

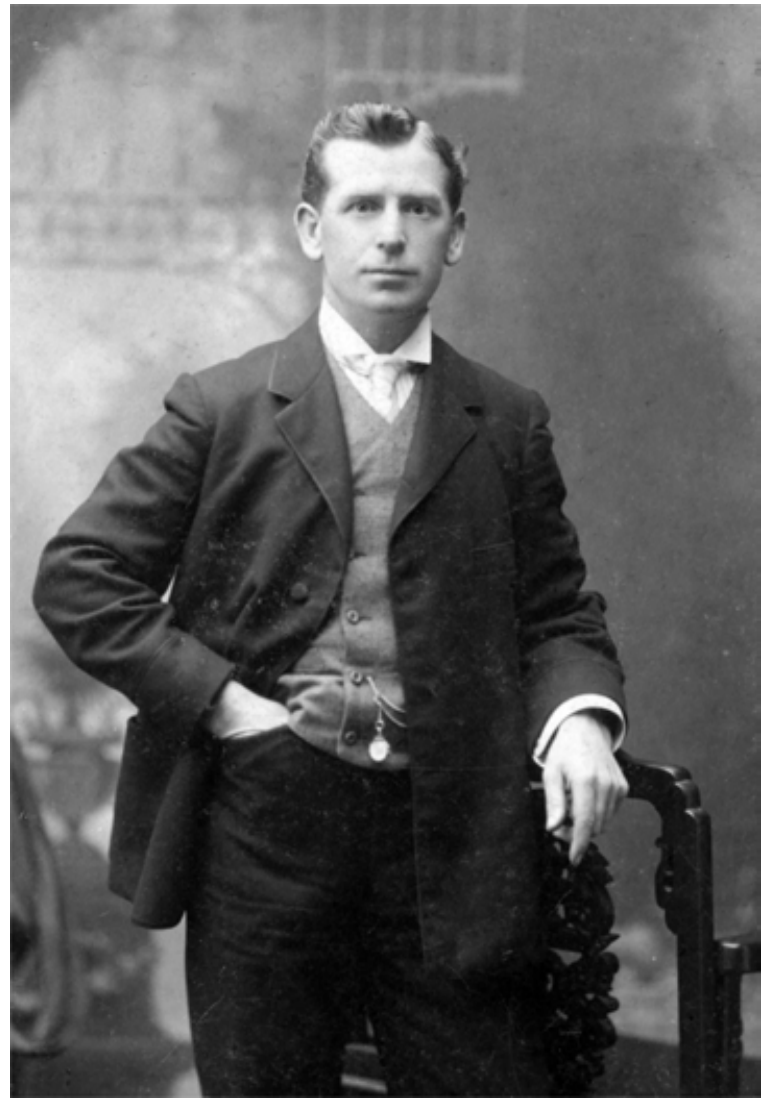

Illustration 2: Captain Matthew Ryan (before 1918) photographed by Skene Lowe. Courtesy Beaton Institute, Cape Breton University. months but he eventually cleared Montevideo with the Donahue in early October and

56 Wright, Lewis \& Dryden, 435; Archie H. Willis, "In the days of sealing," Victoria Colonist, 28 June 1970, 5.

57 Wright, Lewis \& Dryden, 435n.18; Willis, "In the days of sealing," 5.

58 LAC, Royal Commission to Investigate and Report upon Claims of Certain Canadian Pelagic Sealers, 1913-15, RG 33/107/1/5, v. 1, Testimony of Ryan, Halifax, 2 September 1913, 35.

59 While Canadian sealers sometimes hunted, illegally, around the Falklands, the waters off Uruguay seemed to be the most lucrative. In the Falklands hunting was prohibited during the breeding season by the Seal Fishery Ordnance of 1881 and the Seal Fishery Ordnance of 1899 banned unlicensed hunting. A.B. Dickinson, "Southern Hemisphere Fur Sealing from Atlantic Canada," The American Neptune 49, no. 9 (1989), 278-290.

60 http://museum.gov.ns.ca/mma/wrecks/wrecks/shipwrecks.asp?ID=130 (accessed 12 June 2006). Nova Scotia Archives and Records Management, 1903/1805/133/261; Busch, 211.

61 LAC, RG 13-A-2, v. 1907, f. 1905-48, Pt. 1, Sanford Pelton to Charles Fitzpatrick, Minister of Justice, 16 January 1906, 5-6. 
sailed into Halifax harbour on 3 December 1905 . He had been away 810 days. $^{62}$

Ryan, like the other successful pelagic sealers, managed to get into and out of numerous troubling situations. In the summer of 1910-11, for example, Ryan, on the Hilda $R$, arrived at Campbell Island, 700 kilometres south of New Zealand in the subAntarctic Ocean. He met up with Jack Norton, a kindred spirit, who was there to raise sheep and engage in shore whaling, with an illegal sideline of seal skins. Ryan acquired 300 of them and arranged to return the following year. ${ }^{63}$ Forewarned, the New Zealand Marine Department swore in two special constables, gave them a cover as botanists, and sent them to Campbell Island. But the Nortons had already salted down and hidden over 500 skins. When the Hilda $R$ was sighted in late December the constables were distracted by a touch of hospitality and, under the cover of night, and an exchange, the schooner sailed away. The Hilda $R$ arrived back in Halifax in June 1912 with skins valued at more than $\$ 30,000 .^{64}$

The 1911 Fur Seal Convention ended pelagic sealing in the North Pacific. Ryan continued sealing in the South Atlantic until early 1914. ${ }^{65}$ The First World War halted that practice. Ryan revived the latter in 1920 with the 93-ton schooner Eva June. ${ }^{66}$ He had two more successful seasons and he returned to Halifax in April 1922 with a catch of 2,240 seal skins. ${ }^{67}$ Before leaving for home "practically every man (in the crew) went to the office and asked to have his name put down for the next sealing voyage whenever it would be." ${ }^{\prime 68}$ But the Eva June's voyage that year was the last one by a pelagic sealer out of Halifax. Another era had ended. Incidentally, one of the 200 coats fashioned from that catch could be purchased for only $\$ 800$ in $1924 .^{69}$

These pelagic sealers attracted journalists and novelists. Jack London's Wolf

62 While most of the crew were sent home by the British consul in late may 1905, the first mate, Matt's half brother William and the second mate remained. Halifax Herald, 4 December 1905, 2; Sydney Post, 5 December 1905, 5.

63 Ian S. Kerr, Campbell Island: A History (Wellington 1976), 82-3, 85-6.

64 Ryan paid Norton £120. Kerr, Campbell Island, 85-86.

65 Halifax Herald, 9 July 1914, 11.

66 Canada, Department of Marine, List of Shipping, Sessional Papers, no. 22, 1914 (Ottawa 1914), 281. The vessel's registration number was 116,518. In 1922 the owner was A.J. McDougald, Halifax. Sessional Papers, no. 22, (Ottawa, 1922), 141; Sydney Post, 13 February 1922, 3.

67 Halifax Herald, 14 April 1922, 16.

68 "Seal Hunting in the South Atlantic: A Cruise of 12,000 Miles," Montreal Standard, 24 May 1924, 35. The Cruise of the Eva June (Halifax 1924), Captain Matt Ryan files, Maritime Museum of the Atlantic, states they reached the sealing grounds 45 days out.

69 The Cruise of the Eva June. H.R. Silver, along with three other Halifax businessmen (W.H. Dennis, Reg Corbett and Harry DeWolfe) got the fishermen's race started in 1920, convinced Angus Walters to come onboard to build a new schooner, and introduced him to designer W.J. Roue. The result was the Bluenose. Angus Walters to editor, Halifax Herald, 15 June 1953, 4 . 
Larsen is "one of the most unforgettable figures in American literature." ${ }^{70}$ The Sea-Wolf correctly describes pelagic sealing activity, although Wolf Larsen as an accurate portrayal of Alex MacLean is far more suspect. ${ }^{71}$ Matt Ryan and the Eva June attracted Arthur Hunt Chute. The 1920s was a miserable decade economically in Atlantic Canada. Antimodernism was in full flight in the region; Helen Creighton was tracking down the Folk and Frederick William Wallace published Wooden Ships and Iron Men in 1924. Chute's Far Gold, published in 1927, was a novel about retired Cape Breton sealers heading to the South Atlantic seeking buried treasure, and adventure; their cover was a final sealing expedition. The main character in the book was Captain Gabereau, recently retired to his home village, Arichat, after a career sealing in the Bering Sea, off Japan, the Falklands, South Georgia, and the Southern Ocean. All the locations were in Ryan's logbooks. As he prepared his vessel, the Acadian, for one last supposed hunt, Gabereau took a room in the local inn. The pelagic sealing network was still operating. "[N]umerous strange characters ... began mysteriously to appear ... The bar ... echoed to incessant brawls ... with the coming of this gambling, drinking, fighting and carousing set ... There was Wild Alec MacLean, who years before had burst upon the 'Frisco water front with his tremendous moustache, and ... a career of far adventure ... There was Captain MacAuley, who once calmly invited himself to dinner with the commandant of the Russian guards at Commander Islands, while his men took spoil of the herd." 72 Upon reaching the Southern Ocean the captain couldn't resist an illegal seal hunt. His first mate, Alec MacLean, uncharacteristically urged caution, as "times have changed ... Change be damned," replied the captain, to which the mate replied: "All right, I'm only tellin' ye. Don't forget the Agnes Donahue seized at Montevideo, and classed as pirate, fer havin' a load of pelts aboard." ${ }^{\text {73 }}$ The fictional schooner Acadian was a dead ringer for the Eva June. ${ }^{74}$ Aside from the interesting twist of having a number of real life characters stride into a work of fiction under their own names (the actual Dan MacAulay was from Baddeck, Cape Breton), Far Gold accurately captures the abilities, attitudes and adventures of these mariners. The voyage of the City of San Diego to the Bering Sea in 1883 with Alex and Dan MacLean prompted the expansion of the fleet. Matt Ryan's cruise with the Eva June in 1922 closed that adventurous chapter in maritime history. It is not surprising that the leading maritime characters in the two novels dealing with pelagic sealing in the North Pacific and beyond are based on Cape Bretoners.

70 Earle Labor and Jeanne Campbell Reesman, Jack London, rev. ed. (New York 1994), 58.

71 MacGillivray, Captain Alex MacLean, passim.

72 Arthur Hunt Chute, Far Gold (1927; repr. Halifax 2008), 89-90.

73 Chute, 125.

74 Far Gold, 87-88; Montreal Standard, 24 May 1924, 35. 


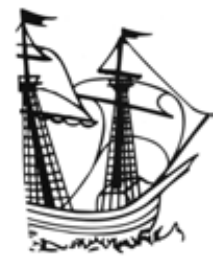

\section{AWARDS PRESENTED BY \\ THE CANADIAN NAUTICAL RESEARCH SOCIETY}

The Keith Matthews Best Book Award

A prize of $\$ 1,000$ awarded for a book by a Canadian author on any topic of maritime history, or by a scholar of any nationality on a topic of Canadian maritime history, published in a calendar year.

The Gerry Panting New Scholar's Award

For a scholar new to the field of maritime history, by which is meant within five years of their last degree, $\$ 1,000$ to travel to a CNRS annual conference to present a paper. The recipient is expected to offer the paper to The Northern Mariner/Le marin du nord for publication.

The Jacques Cartier MA Prize

An award of $\$ 500$ for the best master's thesis on a topic of maritime history completed by a student at a Canadian university, or a Canadian at a foreign university.

The Keith Matthews Best Article Award

A prize of $\$ 250$ awarded for the best article published in The Northern Mariner/Le marin du nord in a calendar year.

All awards are normally announced at the society's annual conference, held between May and August. All inquiries about eligibility and application procedure should be directed to the chair of the Awards Committee:

Dr William Glover

CNRS Awards Committee Chair

163 Churchill Crescent

Kingston, ON K7L 4N3

email: williamglover@sympatico.ca 